\title{
Synthesis, Characterization, and Evaluation of Antimicrobial and Antifertility Efficacy of Heterobimetallic Complexes of Copper (II)
}

\author{
Ashu Chaudhary and Anshul Singh \\ Department of Chemistry, Kurukshetra University, Kurukshetra 136 119, India \\ Correspondence should be addressed to Ashu Chaudhary; ashuchaudhary21@gmail.com
}

Received 10 May 2017; Revised 6 July 2017; Accepted 30 July 2017; Published 2 October 2017

Academic Editor: Hakan Arslan

Copyright ( 2017 Ashu Chaudhary and Anshul Singh. This is an open access article distributed under the Creative Commons Attribution License, which permits unrestricted use, distribution, and reproduction in any medium, provided the original work is properly cited.

\begin{abstract}
Heterobimetallic complexes of the copper with remarkable antimicrobial and antifertility action have been synthesized by the conventional method by reacting $\mathrm{CuCl}_{2}$ and o-phenylenediamine in the methanolic medium forming the mononuclear complex of the type $\left[\mathrm{Cu}\left(\mathrm{C}_{6} \mathrm{H}_{8} \mathrm{~N}_{2}\right)_{2}\right] \mathrm{Cl}_{2}$ which was further treated with group 4 or 14 organometallic dichlorides $\left(\mathrm{Ph}_{2} \mathrm{M}^{\prime} \mathrm{Cl}_{2}, \mathrm{Me}_{2} \mathrm{M}^{\prime} \mathrm{Cl}_{2}\right.$, and $\left.\mathrm{Cp}_{2} \mathrm{M}^{\prime \prime} \mathrm{Cl}_{2}\right)\left[\mathrm{M}^{\prime}=\mathrm{Sn}, \mathrm{Si}\right.$, and $\left.\mathrm{M}^{\prime \prime}=\mathrm{Ti}, \mathrm{Zr}\right]$ leading to formation of heterobimetallic complexes. All the synthesized complexes were characterized in the light of various physicochemical techniques like elemental analyses, conductivity measurements, molecular weight determination, electronic and infrared spectra, electronic spin resonance, X-ray, and mass spectral studies. The in vitro antibacterial activity of synthesized complexes against Escherichia coli and Staphylococcus aureus was tested to evaluate their inhibiting activities. The antifungal activities of mono- and heterobimetallic complexes were studied by screening the compounds against Fusarium oxysporum and Alternaria alternata. These complexes were then investigated to reveal their effect on the reproductive organs of male rats. The treatment has shown substantial decline in the sperm motility and density signifying the imperious antifertility activity.
\end{abstract}

\section{Introduction}

Over the past few decades, studies on heterobimetallic complexes have aroused as a conspicuous field in the quest for new chemistry because of their plausible applications in fundamental, applied sciences, and coordination chemistry beneficial in industrial and synthetic processes such as catalysis, photochemistry, and biological systems. Heterobimetallic complexes have gained augmented research interest in recent years owing to the presence of two different metals which contributes to captivating structures and results in imperative applications.

In recent years, bimetallic complexes encompassing two different metal centers have acknowledged escalated consideration owing to the assumption that their reactivity should vary significantly from that of monometallic complexes or homobimetallic complexes [1]. The physical properties of these complexes are greatly affected by the presence of two metals in the same molecule along with an appreciable change in their reactivity. This is moreover due to the substantial modification in the individual properties of the metals or in the development of unique characteristics, which do not occur in monometallic compounds [2]. Varying applications of heterobimetallic complexes have been thoroughly explored which are found to be arising from the bifunctionality of the differing metal atoms [3].

Heterobimetallic complexes with transition metal ions have been subject of interest and entangled in biological processes of life [4]. Among the essential heavy metal ions in the human body, $\mathrm{Cu}^{2+}$ is third in abundance after $\mathrm{Fe}^{3+}$ and $\mathrm{Zn}^{2+}$, and it plays very important role in several biological processes. Furthermore, many bimetallic complexes embroiling transition metals have been found to have potentials as antibacterial, anticancer, and antidiabetic agents [5].

The treatment of infectious diseases still remains an important and exigent problem because of an amalgamation 
of factors comprising emerging contagious ailments and the escalating number of multidrug resistant microbial pathogens. Despite the availability of enormous number of antibiotics and chemotherapeutics for medical use, the emergence of deep-rooted antibiotic resistance created in the last decades revealed an extensive medical need for new classes of antimicrobial agents. There is an essential need for the discovery of new compounds proficient at antimicrobial activity, possibly acting through mechanism of action and dissimilar from well-known classes of antimicrobial agents to which numerous clinically relevant pathogens are now resistant. Keeping all these fascinating facts under consideration, we have synthesized and characterized the monometallic and heterobimetallic complexes of copper along with group 4 and 14 metals which were further screened against a variety of pathogenic organisms.

Expeditiously growing population and inadequate sources are believed to be the most critical worldwide problems today. This upturn in the world population has burgeoned the benefits of economic and technological advancement. Fertility control is very essential for maintaining satisfactory standards in the developing countries. Hence, there is an abrupt requirement for a reasonable, safe, and effective contraceptive. Many inorganic compounds have been examined and applied for antifertility activity. All this work has emanated our interest in the development of a new series of heterobimetallic complexes with an aim to assess their effect on fertility and other reproductive organs of male albino rats. All the synthesized complexes were found possessing remarkable antifertility activity with discernable reduction in sperm motility and density.

\section{Experimental}

\subsection{Synthesis}

2.1.1. Materials and Methods. All the solvents used were first distilled and dried before use. Anhydrous $\mathrm{CuCl}_{2}$, ophenylenediamine, and organometallic dichlorides of group 4 and $14\left(\mathrm{Ph}_{2} \mathrm{M}^{\prime} \mathrm{Cl}_{2}, \mathrm{Me}_{2} \mathrm{M}^{\prime} \mathrm{Cl}_{2}\right.$, and $\left.\mathrm{Cp}_{2} \mathrm{M}^{\prime \prime} \mathrm{Cl}_{2}\right)$ were used as obtained. All the chemicals used for the synthesis of complexes were of AR grade.

2.1.2. Synthesis of Monometallic Complex $\left[\mathrm{Cu}\left(\mathrm{C}_{6} \mathrm{H}_{8} \mathrm{~N}_{2}\right)_{2}\right] \mathrm{Cl}_{2}$. Anhydrous $\mathrm{CuCl}_{2}(1.34 \mathrm{~g}, 0.01 \mathrm{~mol})$ was dissolved in hot methanol in a $100 \mathrm{~mL}$ round bottomed flask. A solution of o-phenylenediamine in methanol was added to the above solution in 1:2 stoichiometric proportions with a constant stirring of about 10-12 hrs. The complex thus obtained was washed and recrystallized from methanol and dried under vacuum.

2.1.3. Synthesis of Heterobimetallic Complex $\left[\mathrm{Cu}\left(\mathrm{C}_{6} \mathrm{H}_{6} \mathrm{~N}_{2}\right)_{2}\right.$ $\mathrm{Sn}_{2}(\mathrm{Ph})_{4} \mathrm{Cl}_{2}$ ]. Monometallic complex $(3.50 \mathrm{~g}, 0.01 \mathrm{~mol})$ dissolved in hot methanol was then treated with solution of $6.88 \mathrm{~g}, 0.02 \mathrm{~mol}$ of $\mathrm{Ph}_{2} \mathrm{SnCl}_{2}$ in hot methanol in $1: 2$ stoichiometric proportions. In the reaction, a solid product was obtained after keeping the reaction mixture overnight at room temperature. The products formed were washed with hot methanol and then dried under vacuum.
On replacing $\mathrm{Ph}_{2} \mathrm{SnCl}_{2}$, the other complexes were obtained in the similar manner using $\mathrm{Me}_{2} \mathrm{SnCl}_{2}, \mathrm{Ph}_{2} \mathrm{SiCl}_{2}$, $\mathrm{Cp}_{2} \mathrm{TiCl}_{2}$, and $\mathrm{Cp}_{2} \mathrm{ZrCl}_{2}$ respectively.

2.2. Analytical Methods and Physical Measurements. Molar conductance of the compounds was measured in $10^{-3} \mathrm{M}$ DMF solution on a Systronic model 305 conductivity bridge. The IR spectra $\left(4000-200 \mathrm{~cm}^{-1}\right)$ were recorded on a model Nicolet Magna FTIR-550 spectrophotometer in the form of $\mathrm{KBr}$ pellets. The far infrared spectra of the complexes were recorded on the same spectrophotometer in Nujol Mulls using CsI cell. Molecular weights were determined by the Rast Camphor method. Metal contents were determined gravimetrically. Electronic spectra in dimethyl sulphoxide were recorded, using method as the solvent on a UV160A Shimadzu spectrophotometer. X-ray powder diffraction spectra of the compound were obtained on a Philips (Model P.W. 1840) automatic diffractometer while EPR spectra of the complexes were recorded on a Varian E-4 EPR spectrometer. Nitrogen and chlorine were estimated by Kjeldahl's method and Volhard's method, respectively.

2.3. Antimicrobial Assay. Heterobimetallic complexes with macrocyclic framework have engendered copious research in the current years, due to their probable applications in catalysis, applied sciences, photochemistry, and biological systems. An escalating interest in developing better fungicides and bactericides has prompted us to assess the microbial efficacy of all the synthesized monometallic and heterobimetallic complexes.

(i) Antifungal Activity Studies. The antifungal activities were evaluated against Alternaria alternata and Fusarium oxysporum by Radial growth method. The potato dextrose agar medium was prepared by dissolving glucose $(20 \mathrm{~g})$, starch (20 g), agar-agar $(20 \mathrm{~g})$, and $1000 \mathrm{~mL}$ of distilled water at $25 \pm$ $2^{\circ} \mathrm{C}$. Bavistin was used as standard fungicide. The compounds at 100 and $200 \mathrm{ppm}$ concentrations in methanol were then mixed in the medium using a small amount of DMF for initial solution (Figure 1). The linear growth of the fungus was determined by measuring the diameter of the colony after 96 hrs [6]. Growth inhibition was calculated using formula:

$$
\% \text { inhibition }=C-\frac{T}{C} \times 100,
$$

where $C$ and $T$ are the diameters of the fungal colony in the control and test plates, respectively (Table 1).

(ii) Antibacterial Activity Studies. The synthesized complexes were tested against Escherichia coli and Staphylococcus aureus at 500 and $1000 \mathrm{ppm}$ concentrations. In this case, streptomycin was used as standard (Figure 2). Inhibition zone technique was used to evaluate antibacterial activities [7]. In this technique, nutrient agar medium (peptone, beef extract, $\mathrm{NaCl}$, and agar-agar) and $5 \mathrm{~mm}$ diameter paper discs (Whatman No.1) filter paper were used. The compounds were dissolved in methanol in 500 and 1000 ppm concentrations. The filter paper discs were soaked in these solutions of the compounds, dried, and then placed in the Petri plates 
TABLE 1: Fungicidal screening data of the $\mathrm{Cu}(\mathrm{II})$ complexes (percent growth inhibition after $96 \mathrm{hrs}$ at $25 \pm 2^{\circ} \mathrm{C}$, Conc. in ppm).

\begin{tabular}{lcccc}
\hline Complex & \multicolumn{2}{c}{ Alternaria alternata } & \multicolumn{2}{c}{ Fusarium oxysporum } \\
& 100 ppm & 200 ppm & 100 ppm & 2600 ppm \\
\hline$\left[\mathrm{Cu}\left(\mathrm{C}_{6} \mathrm{H}_{8} \mathrm{~N}_{2}\right)_{2}\right] \mathrm{Cl}_{2}$ & 23 & 30 & 40 & 34 \\
{$\left[\mathrm{Cu}\left(\mathrm{C}_{6} \mathrm{H}_{6} \mathrm{~N}_{2}\right)_{2} \mathrm{Sn}_{2}(\mathrm{Ph})_{4} \mathrm{Cl}_{2}\right]$} & 36 & 41 & 47 & 51 \\
{$\left[\mathrm{Cu}\left(\mathrm{C}_{6} \mathrm{H}_{6} \mathrm{~N}_{2}\right)_{2} \mathrm{Sn}_{2}(\mathrm{Me})_{4} \mathrm{Cl}_{2}\right]$} & 42 & 52 & 54 & 59 \\
{$\left[\mathrm{Cu}\left(\mathrm{C}_{6} \mathrm{H}_{6} \mathrm{~N}_{2}\right)_{2} \mathrm{Si}_{2}(\mathrm{Ph})_{4} \mathrm{Cl}_{2}\right]$} & 49 & 60 & 30 & 35 \\
{$\left[\mathrm{Cu}\left(\mathrm{C}_{6} \mathrm{H}_{6} \mathrm{~N}_{2}\right)_{2} \mathrm{Ti}_{2}(\mathrm{Cp})_{4} \mathrm{Cl}_{2}\right]$} & 26 & 34 & 39 & 36 \\
{$\left[\mathrm{Cu}\left(\mathrm{C}_{6} \mathrm{H}_{6} \mathrm{~N}_{2}\right)_{2} \mathrm{Zr}_{2}(\mathrm{Cp})_{4} \mathrm{Cl}_{2}\right]$} & 30 & 37 & 100 & 100 \\
Bavistin & 100 & 100 & & 41 \\
\hline
\end{tabular}

TABLE 2: Bacterial screening data of $\mathrm{Cu}(\mathrm{II})$ complexes (percent growth inhibition after $36 \mathrm{hrs}$ at $30 \pm 1^{\circ} \mathrm{C}$ ).

\begin{tabular}{|c|c|c|c|c|}
\hline \multirow{2}{*}{ Complex } & \multicolumn{2}{|c|}{ Escherichia coli } & \multicolumn{2}{|c|}{ Staphylococcus aureus } \\
\hline & $500 \mathrm{ppm}$ & $1000 \mathrm{ppm}$ & $500 \mathrm{ppm}$ & $1000 \mathrm{ppm}$ \\
\hline$\left[\mathrm{Cu}\left(\mathrm{C}_{6} \mathrm{H}_{8} \mathrm{~N}_{2}\right)_{2}\right] \mathrm{Cl}_{2}$ & 3 & 5 & 2 & 4 \\
\hline$\left[\mathrm{Cu}\left(\mathrm{C}_{6} \mathrm{H}_{6} \mathrm{~N}_{2}\right)_{2} \mathrm{Sn}_{2}(\mathrm{Ph})_{4} \mathrm{Cl}_{2}\right]$ & 5 & 7 & 3 & 5 \\
\hline$\left[\mathrm{Cu}\left(\mathrm{C}_{6} \mathrm{H}_{6} \mathrm{~N}_{2}\right)_{2} \mathrm{Sn}_{2}(\mathrm{Me})_{4} \mathrm{Cl}_{2}\right]$ & 6 & 9 & 5 & 6 \\
\hline$\left[\mathrm{Cu}\left(\mathrm{C}_{6} \mathrm{H}_{6} \mathrm{~N}_{2}\right)_{2} \mathrm{Si}_{2}(\mathrm{Ph})_{4} \mathrm{Cl}_{2}\right]$ & 7 & 11 & 8 & 5 \\
\hline$\left[\mathrm{Cu}\left(\mathrm{C}_{6} \mathrm{H}_{6} \mathrm{~N}_{2}\right)_{2} \mathrm{Ti}_{2}(\mathrm{Cp})_{4} \mathrm{Cl}_{2}\right]$ & 4 & 5 & 2 & 3 \\
\hline$\left[\mathrm{Cu}\left(\mathrm{C}_{6} \mathrm{H}_{6} \mathrm{~N}_{2}\right)_{2} \mathrm{Zr}_{2}(\mathrm{Cp})_{4} \mathrm{Cl}_{2}\right]$ & 4 & 7 & 3 & 4 \\
\hline Streptomycin & 17 & 18 & 15 & 17 \\
\hline
\end{tabular}

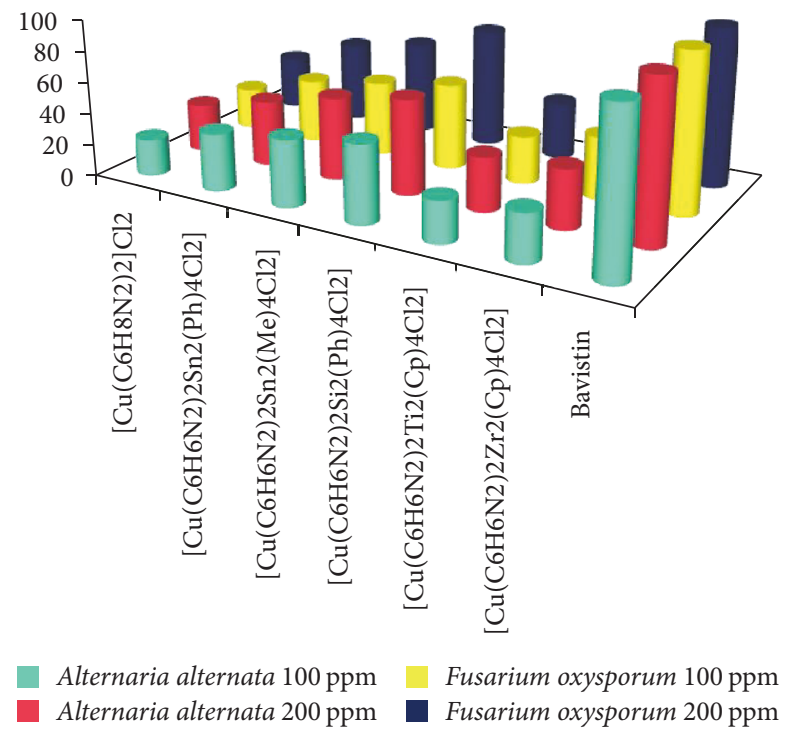

FIGURE 1: Antifungal activity of synthesized monometallic and heterobimetallic complexes.

previously seeded with the test organism. The Petri dishes were stored in an incubator at $30 \pm 1^{\circ} \mathrm{C}$ for $36 \mathrm{hrs}$. The zone of inhibition thus formed around each disc containing the test compound was measured accurately (Table 2).

2.4. Antifertility Activity Studies. The antifertility activity of monometallic and heterobimetallic complexes was evaluated by using male albino rats weighing 180-200 g which were housed in cages by maintaining the standard conditions

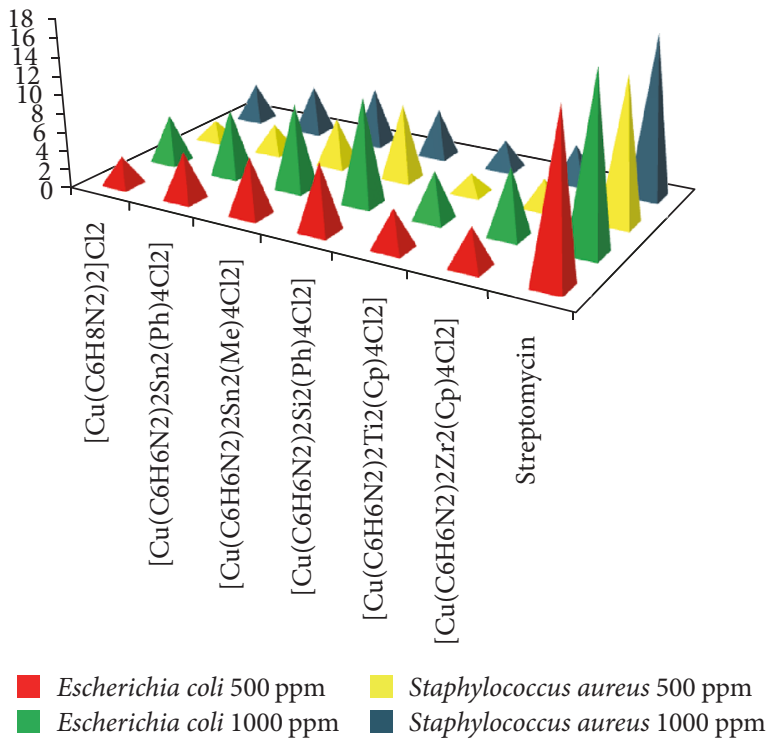

FIGURE 2: Antibacterial activity of synthesized monometallic and heterobimetallic complexes.

(12: 12 light and dark cycle; $25 \pm 3^{\circ} \mathrm{C}$ and $35-60 \%$ relative humidity). The animals of groups were fed with food pellet acquired from Ashirwad Industries, Chandigarh, and the tap water was supplied ad libitum. These rats were equally divided into groups with six rats present in each group. Group A animals were kept as control and were given olive oil only. The animals of group B were treated with monometallic complex of copper (II) with a dose of about $30 \mathrm{mg} / \mathrm{kg}$ body weight for a period of about 60 
TABLE 3: Sperm dynamics and fertility after the administration of synthesized complexes.

\begin{tabular}{lcccccc}
\hline Treatment & $\begin{array}{c}\text { Number of } \\
\text { males }\end{array}$ & $\begin{array}{c}\text { Number of } \\
\text { females }\end{array}$ & $\begin{array}{c}\text { Number of } \\
\text { pregnant } \\
\text { females }\end{array}$ & $\begin{array}{c}\text { Sperm motility (cauda } \\
\text { epididymis) (\%) }\end{array}$ & $\begin{array}{c}\text { Sperm density (cauda } \\
\text { epididymis) (million/ml) }\end{array}$ & Fertility Test (\%) \\
\hline Group A & 6 & 12 & $12 / 12$ & $66.73 \pm 1.33$ & $54.5 \pm 0.49$ & $100(+\mathrm{ve})$ \\
Group B & 6 & 12 & $8 / 12$ & $48.59 \pm 1.67$ & $31.69^{* *} \pm 2.48$ & $35(-\mathrm{ve})$ \\
Group C & 6 & 12 & $5 / 12$ & $38.84 \pm 2.36$ & $18.17 \pm 3.39$ & $60(-\mathrm{ve})$ \\
Group D & 6 & 12 & $3 / 12$ & $35.45^{* *} \pm 2.35$ & $14.5^{* *} \pm 0.29$ & $75(-\mathrm{ve})$ \\
Group E & 6 & 12 & $4 / 12$ & $30.65 \pm 3.66$ & $17.22^{* *} \pm 0.69$ & $70(-\mathrm{ve})$ \\
Group F & 6 & 12 & $1 / 12$ & $26.59^{* *} \pm 1.67$ & $10.01^{* *} \pm 0.22$ & $90(-\mathrm{ve})$ \\
\hline
\end{tabular}

${ }^{* *} P \leq 0.01$ = highly-significant.

TABLE 4: Effect of synthesized complexes on weight of reproductive organs of male rats.

\begin{tabular}{|c|c|c|c|c|c|c|c|}
\hline \multirow{2}{*}{ Treatment } & \multicolumn{2}{|c|}{ Body weight (gm) } & \multicolumn{5}{|c|}{ Tissue weight (mg/100 gm body weight) } \\
\hline & Initial & Final & Testes & Epididymus & Seminal Vesicle & Ventral Prostrate & Vas Deference \\
\hline Group A & $192.5 \pm 5.45$ & $212.5 \pm 4.51$ & $1032.09 \pm 12.50$ & $298.13 \pm 4.86$ & $237.21 \pm 8.33$ & $160.48 \pm 4.32$ & $72.05 \pm 1.50$ \\
\hline Group B & $186.7 \pm 18.00$ & $206 \pm 17.04$ & $641.09^{*} \pm 26.87$ & $243.13^{*} \pm 5.78$ & $207.21^{*} \pm 14.28$ & $128.92^{*} \pm 1.34$ & $40.04^{* *} \pm 0.89$ \\
\hline Group C & $186.25 \pm 3.35$ & $208 \pm 8.62$ & $545.16^{* *} \pm 12.19$ & $208.21^{* *} \pm 9.20$ & $158.97^{* *} \pm 8.00$ & $127.27^{* *} \pm 5.05$ & $37.3^{* *} \pm 0.32$ \\
\hline Group D & $190.5 \pm 8.84$ & $212 \pm 9.87$ & $489.03^{* *} \pm 12.50$ & $191.95^{* *} \pm 4.86$ & $138.43^{* *} \pm 8.33$ & $95.41^{* *} \pm 3.82$ & $42.05^{* *} \pm 1.50$ \\
\hline Group E & $185 \pm 6.96$ & $202.75 \pm 8.70$ & $549.35^{* *} \pm 8.62$ & $203.39 \pm 2.88$ & $149.67^{* *} \pm 4.27$ & $109.49^{* *} \pm 0.93$ & $33.41^{* *} \pm 2.73$ \\
\hline Group F & $187.5 \pm 5.38$ & $205 \pm 17.38$ & $451.08^{* *} \pm 6.23$ & $162.75^{* *} \pm 1.86$ & $123.73^{* *} \pm 4.82$ & $97.45^{* *} \pm 3.29$ & $41.24^{* *} \pm 0.80$ \\
\hline
\end{tabular}

${ }^{*} P \leq 0.01=$ significant; ${ }^{* *} P \leq 0.001=$ highly-significant.

days, while groups $\mathrm{C}, \mathrm{D}, \mathrm{E}$, and $\mathrm{F}$ were treated with heterobimetallic complexes $\left\{\left[\mathrm{Cu}\left(\mathrm{C}_{6} \mathrm{H}_{6} \mathrm{~N}_{2}\right)_{2} \mathrm{Sn}_{2}(\mathrm{Ph})_{4} \mathrm{Cl}_{2}\right],[\mathrm{Cu}\right.$ $\left.\left(\mathrm{C}_{6} \mathrm{H}_{6} \mathrm{~N}_{2}\right)_{2} \mathrm{Sn}_{2}(\mathrm{Me})_{4} \mathrm{Cl}_{2}\right] \quad\left[\mathrm{Cu}\left(\mathrm{C}_{6} \mathrm{H}_{6} \mathrm{~N}_{2}\right)_{2} \mathrm{Si}_{2}(\mathrm{Ph})_{4} \mathrm{Cl}_{2}\right]$, and $\left.\left[\mathrm{Cu}\left(\mathrm{C}_{6} \mathrm{H}_{6} \mathrm{~N}_{2}\right)_{2} \mathrm{Ti}_{2}(\mathrm{Cp})_{4} \mathrm{Cl}_{2}\right]\right\}$ of about the same dose dissolved in olive oil and for relatively analogous time period. Near the end of the experiment, that is, on day 55, each male was housed individually with two estrous females for 3-5 days. The females were scheduled for laparotomy 2 weeks later to determine the number and viability of fetuses. After mating, males were removed for autopsy. The motility and density of cauda epididymal spermatozoa was assessed using a hemocytometer. All the recorded values of body/organs weight, sperm dynamics, hematological parameters, and tissue biochemistry were expressed in the terms of mean \pm SEM. The data were analyzed statistically by using Student's "t-"test and the significance of difference was set at $P<0.01$ and $P<0.001$ as observed in Tables $3-5$ and graphically represented in Figures 3-5.

\section{Results and Discussions}

Cupric chloride reacts with o-phenylenediamine leading to formation of mononuclear complex which on further treatment with organometallic dichlorides of group 4 or 14 resulted in formation of novel series of heterobimetallic complexes of copper.

All the reactions proceeded slickly. The complexes were isolated as coloured solids, and their formation was ascertained on the basis of elemental analysis, infrared, esr, mass, and electronic spectral data. The molar conductance values of heterobimetallic complexes measured in DMF $\left(18-33 \mathrm{ohm}^{-1} \mathrm{~mol}^{-1} \mathrm{~cm}^{2}\right)$ showed them to be nonelectrolytes.

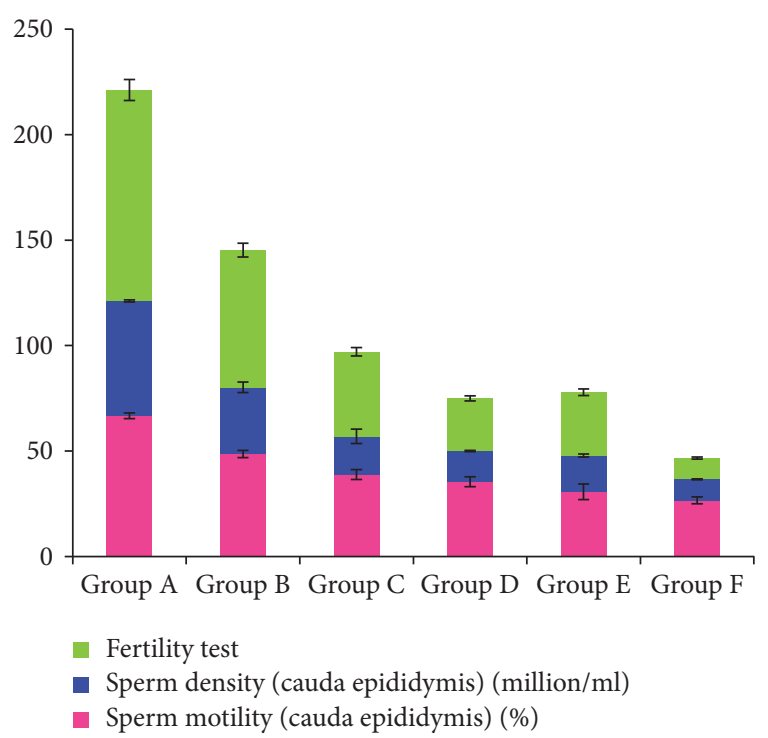

FIGURE 3: Altered sperm dynamics and fertility test after treatment with precursors and their complexes.

The analytical and physical data of the synthesized complexes have been summarized in Table 6 .

3.1. Infrared Spectra. The IR spectra of the mononuclear as well as bimetallic complexes were recorded (Table 7) and a relative study confirmed the formation of heterobimetallic complexes with the anticipated coordination pattern. The primary amine exhibits a band at higher frequency than that of the corresponding secondary amine. In case of 
TABLE 5: Biochemical changes in the male rats after treatment with the synthesized complexes.

\begin{tabular}{lcccc}
\hline \multirow{2}{*}{ Treatment } & \multicolumn{2}{c}{ Cholesterol $(\mathrm{mg} / \mathrm{gm})$} & \multicolumn{2}{c}{ Glycogen $(\mathrm{mg} / \mathrm{gm})$} \\
& Testes & Liver & Testes & Liver \\
\hline Group A & $8.03 \pm 0.16$ & $16.98 \pm 0.04$ & $4.77 \pm 0.38$ & $22.83 \pm 0.71$ \\
Group B & $9.83 \pm 0.26$ & $15.84 \pm 0.07$ & $3.62^{* *} \pm 0.19$ & $21.99 \pm 0.44$ \\
Group C & $9.45^{*} \pm 0.33$ & $14.64^{*} \pm 0.03$ & $3.19^{* *} \pm 0.32$ & $21.13^{*} \pm 0.30$ \\
Group D & $10.06^{* *} \pm 0.28$ & $13.92^{* *} \pm 0.07$ & $3.53^{* *} \pm 0.26$ & $20.04^{* *} \pm 0.85$ \\
Group E & $11.6^{* *} \pm 0.14$ & $13.82^{* *} \pm 0.05$ & $2.44^{*} \pm 0.46$ & $18.85^{* *} \pm 0.67$ \\
Group F & $12.7^{* *} \pm 0.34$ & $11.98^{* *} \pm 0.04$ & $18.06^{* *} \pm 0.47$ \\
\hline
\end{tabular}

${ }^{*} P<0.01$ = significant; ${ }^{* *} P<0.001=$ highly-significant.

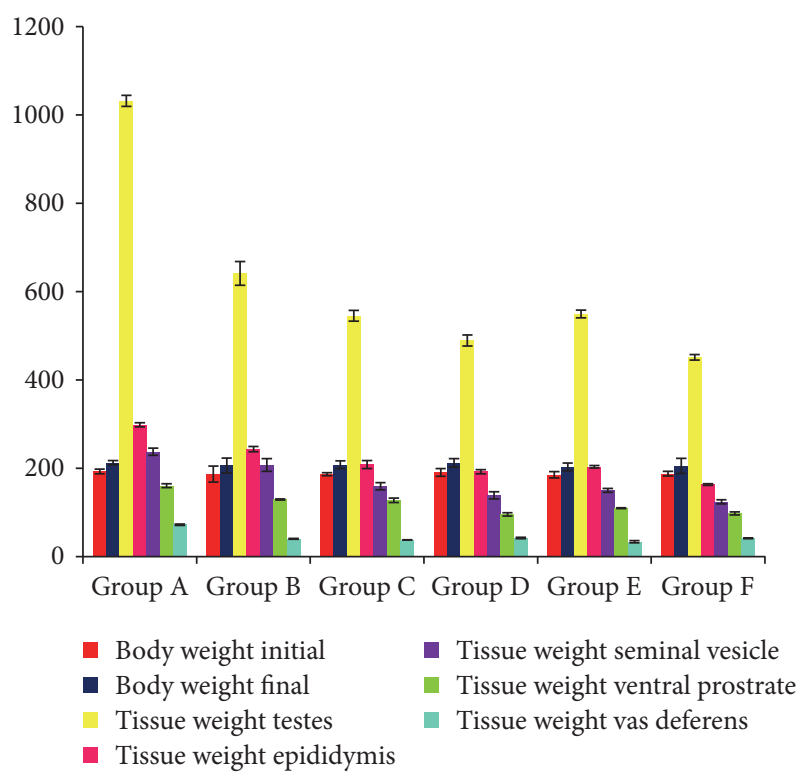

FIGURE 4: Alteration in the body weight and weight of reproductive organs after treatment with the synthesized monometallic and heterobimetallic complexes.

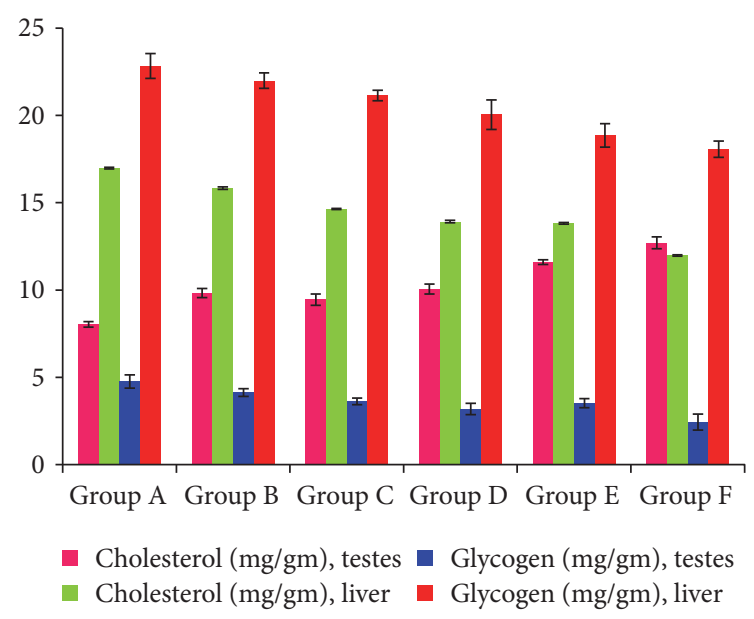

FIGURE 5: Effects of the synthesized complexes on the cholesterol and glycogen content of tissues.

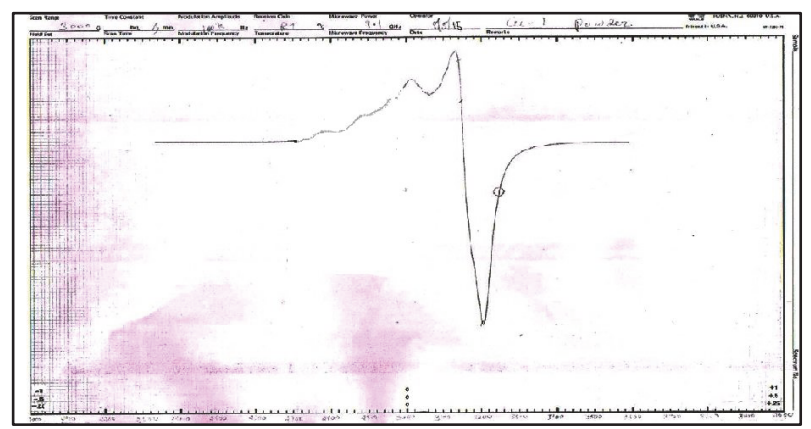

FIgURE 6: The $\mathrm{X}$ band ESR spectrum of mononuclear complex $\left[\mathrm{Cu}\left(\mathrm{C}_{6} \mathrm{H}_{8} \mathrm{~N}_{2}\right)_{2}\right] \mathrm{Cl}_{2}$.

mononuclear complex, a broad and strong band is observed for $\nu(\mathrm{N}-\mathrm{H})$ in the range of $3218-3255 \mathrm{~cm}^{-1}$ which swings over to lower frequency region in case of bimetallic complexes [8] evidently specifying the formation of bond between group 14 metal and nitrogen, while bands due to $\delta(\mathrm{N}-\mathrm{H})$ appear in the region of $1529-1540 \mathrm{~cm}^{-1}$ with no evident change after chelation [9]. Aromatic ring $(\mathrm{C}=\mathrm{C})$ stretching appears at 1645 , 1529 , and $1453 \mathrm{~cm}^{-1}$, while $(\mathrm{C}-\mathrm{H})$ and $(\mathrm{C}-\mathrm{N})$ stretching were assigned at 3059 and $843 \mathrm{~cm}^{-1}$, respectively. Bands of medium intensity in the range of $422-580 \mathrm{~cm}^{-1}$ are attributed to $\nu(\mathrm{M}$ $\mathrm{N})$ vibrations [10]. In case of heterobimetallic complexes with cyclopentadienyl ring, IR bands appear at 3000 for $\nu(\mathrm{C}-\mathrm{H})$, 1435 for $\nu(\mathrm{C}-\mathrm{C}), 1028$ for $\delta(\mathrm{C}-\mathrm{H})$ in plane, and 812 for $\delta(\mathrm{C}-\mathrm{H})$ out of plane vibrations. In addition, bands due to $\left(\mathrm{Ti}-\mathrm{C}_{5} \mathrm{H}_{5}\right)$ and $\left(\mathrm{Zr}-\mathrm{C}_{5} \mathrm{H}_{5}\right)$ appear at 446 and $443 \mathrm{~cm}^{-1}$, respectively. A medium intensity band observed in the far IR region of the metal complexes $(460-470) \mathrm{cm}^{-1}$ was assigned to $v(\mathrm{Cu}-\mathrm{N})$. The far IR spectra show a distinct band at $315 \mathrm{~cm}^{-1}$ attributed to $(\mathrm{Cu}-\mathrm{Cl})$ band [11].

3.2. Electron Spin Resonance Spectra. The ESR spectra of monometallic and heterobimetallic complexes were recorded at the room temperature. The observed data showed that in case of monometallic complex $g_{\|}=2.09$ and $g_{\perp}=2.06$, respectively, with $g_{\mathrm{av}}=2.07$. As $g_{\|}>g_{\perp}>2.0023$, it is suggested that the unpaired electron is localized in $d_{x^{2}-y^{2}}$ orbital which indicates the square planar geometry around the $\mathrm{Cu}(\mathrm{II})$ ion [12] (Figure 6). The $g$ values witnessed for heterobimetallic complexes has $g_{\perp}>g_{\|}$suggesting 
TABLE 6: Analytical data and physical properties of the synthesized complexes.

\begin{tabular}{|c|c|c|c|c|c|c|c|c|}
\hline \multirow{2}{*}{ Complex } & \multirow{2}{*}{$\begin{array}{c}\text { Color \& M.P. } \\
\left({ }^{\circ} \mathrm{C}\right)\end{array}$} & \multicolumn{6}{|c|}{ Analysis: found (calc.) (\%) } & \multirow{2}{*}{$\begin{array}{l}\text { Mol. Wt. } \\
\text { found } \\
\text { (calc.) }\end{array}$} \\
\hline & & $\mathrm{C}$ & $\mathrm{H}$ & $\mathrm{N}$ & $\mathrm{Cl}$ & $\mathrm{Cu}$ & $\mathrm{M}^{\prime}$ & \\
\hline$\left[\mathrm{Cu}\left(\mathrm{C}_{6} \mathrm{H}_{8} \mathrm{~N}_{2}\right)_{2}\right] \mathrm{Cl}_{2}$ & $\begin{array}{l}\text { Brown } \\
240\end{array}$ & $\begin{array}{c}41.12 \\
(41.09)\end{array}$ & $\begin{array}{c}4.65 \\
(4.60)\end{array}$ & $\begin{array}{c}15.98 \\
(15.97)\end{array}$ & $\begin{array}{l}20.24 \\
(20.22)\end{array}$ & $\begin{array}{c}18.14 \\
(18.12)\end{array}$ & - & $\begin{array}{c}355.62 \\
(350.73)\end{array}$ \\
\hline$\left[\mathrm{Cu}\left(\mathrm{C}_{6} \mathrm{H}_{6} \mathrm{~N}_{2}\right)_{2} \mathrm{Sn}_{2}(\mathrm{Ph})_{4} \mathrm{Cl}_{2}\right]$ & $\begin{array}{c}\text { Dark brown } \\
232\end{array}$ & $\begin{array}{c}48.25 \\
(48.23)\end{array}$ & $\begin{array}{c}4.09 \\
(4.05)\end{array}$ & $\begin{array}{c}6.27 \\
(6.25)\end{array}$ & $\begin{array}{l}7.94 \\
(7.91)\end{array}$ & $\begin{array}{c}7.15 \\
(7.09)\end{array}$ & $\begin{array}{c}26.52 \\
(26.48)\end{array}$ & $\begin{array}{c}898.50 \\
(896.57)\end{array}$ \\
\hline$\left[\mathrm{Cu}\left(\mathrm{C}_{6} \mathrm{H}_{6} \mathrm{~N}_{2}\right)_{2} \mathrm{Sn}_{2}(\mathrm{Me})_{4} \mathrm{Cl}_{2}\right]$ & $\begin{array}{c}\text { Dark brown } \\
209\end{array}$ & $\begin{array}{l}29.86 \\
(29.83)\end{array}$ & $\begin{array}{c}3.76 \\
(3.75)\end{array}$ & $\begin{array}{c}8.74 \\
(8.70)\end{array}$ & $\begin{array}{c}11.2 \\
(11.0)\end{array}$ & $\begin{array}{c}9.88 \\
(9.86)\end{array}$ & $\begin{array}{l}36.88 \\
(36.85)\end{array}$ & $\begin{array}{c}650.00 \\
(644.26)\end{array}$ \\
\hline$\left[\mathrm{Cu}\left(\mathrm{C}_{6} \mathrm{H}_{6} \mathrm{~N}_{2}\right)_{2} \mathrm{Si}_{2}(\mathrm{Ph})_{4} \mathrm{Cl}_{2}\right]$ & $\begin{array}{l}\text { Brown } \\
220\end{array}$ & $\begin{array}{l}60.48 \\
(60.45)\end{array}$ & $\begin{array}{c}5.09 \\
(5.07)\end{array}$ & $\begin{array}{c}7.88 \\
(7.83)\end{array}$ & $\begin{array}{l}9.96 \\
(9.91)\end{array}$ & $\begin{array}{c}8.92 \\
(8.88)\end{array}$ & $\begin{array}{c}7.86 \\
(7.85)\end{array}$ & $\begin{array}{c}723.42 \\
(715.33)\end{array}$ \\
\hline$\left[\mathrm{Cu}\left(\mathrm{C}_{6} \mathrm{H}_{6} \mathrm{~N}_{2}\right)_{2} \mathrm{Ti}_{2}(\mathrm{Cp})_{4} \mathrm{Cl}_{2}\right]$ & $\begin{array}{c}\text { Blackish } \\
\text { brown } \\
231\end{array}$ & $\begin{array}{c}54.75 \\
(54.69)\end{array}$ & $\begin{array}{c}4.63 \\
(4.59)\end{array}$ & $\begin{array}{l}7.98 \\
(7.97)\end{array}$ & $\begin{array}{c}10.14 \\
(10.09)\end{array}$ & $\begin{array}{c}9.06 \\
(9.04)\end{array}$ & $\begin{array}{c}13.64 \\
(13.62)\end{array}$ & $\begin{array}{c}708.41 \\
(702.81)\end{array}$ \\
\hline$\left[\mathrm{Cu}\left(\mathrm{C}_{6} \mathrm{H}_{6} \mathrm{~N}_{2}\right)_{2} \mathrm{Zr}_{2}(\mathrm{Cp})_{4} \mathrm{Cl}_{2}\right]$ & $\begin{array}{c}\text { Shiny brown } \\
228\end{array}$ & $\begin{array}{c}48.72 \\
(48.68) \\
\end{array}$ & $\begin{array}{c}4.14 \\
(4.08) \\
\end{array}$ & $\begin{array}{c}7.13 \\
(7.10) \\
\end{array}$ & $\begin{array}{c}9.12 \\
(8.98) \\
\end{array}$ & $\begin{array}{c}8.07 \\
(8.05) \\
\end{array}$ & $\begin{array}{c}23.15 \\
(23.11) \\
\end{array}$ & $\begin{array}{c}792.00 \\
(789.53) \\
\end{array}$ \\
\hline
\end{tabular}

TABLE 7: IR spectral data (in $\mathrm{cm}^{-1}$ ) of the synthesized monometallic and heterobimetallic complexes.

\begin{tabular}{|c|c|c|c|c|c|}
\hline Complex & $\nu(\mathrm{N}-\mathrm{H})$ & $\delta(\mathrm{N}-\mathrm{H})$ & $\nu(\mathrm{M}-\mathrm{N})$ & $\nu(\mathrm{Cu}-\mathrm{N})$ & $\nu(\mathrm{Cu}-\mathrm{Cl})$ \\
\hline$\left[\mathrm{Cu}\left(\mathrm{C}_{6} \mathrm{H}_{8} \mathrm{~N}_{2}\right)_{2}\right] \mathrm{Cl}_{2}$ & 3250 & 1540 & - & 468 & - \\
\hline$\left[\mathrm{Cu}\left(\mathrm{C}_{6} \mathrm{H}_{6} \mathrm{~N}_{2}\right)_{2} \mathrm{Sn}_{2}(\mathrm{Ph})_{4} \mathrm{Cl}_{2}\right]$ & 3185 & 1536 & 470 & 465 & 315 \\
\hline$\left[\mathrm{Cu}\left(\mathrm{C}_{6} \mathrm{H}_{6} \mathrm{~N}_{2}\right)_{2} \mathrm{Sn}_{2}(\mathrm{Me})_{4} \mathrm{Cl}_{2}\right]$ & 3187 & 1534 & 468 & 465 & 315 \\
\hline$\left[\mathrm{Cu}\left(\mathrm{C}_{6} \mathrm{H}_{6} \mathrm{~N}_{2}\right)_{2} \mathrm{Si}_{2}(\mathrm{Ph})_{4} \mathrm{Cl}_{2}\right]$ & 3182 & 1536 & 581 & 463 & 315 \\
\hline$\left[\mathrm{Cu}\left(\mathrm{C}_{6} \mathrm{H}_{6} \mathrm{~N}_{2}\right)_{2} \mathrm{Ti}_{2}(\mathrm{Cp})_{4} \mathrm{Cl}_{2}\right]$ & 3185 & 1536 & 525 & 464 & 315 \\
\hline$\left[\mathrm{Cu}\left(\mathrm{C}_{6} \mathrm{H}_{6} \mathrm{~N}_{2}\right)_{2} \mathrm{Zr}_{2}(\mathrm{Ph})_{4} \mathrm{Cl}_{2}\right]$ & 3190 & 1536 & 530 & 465 & 315 \\
\hline
\end{tabular}

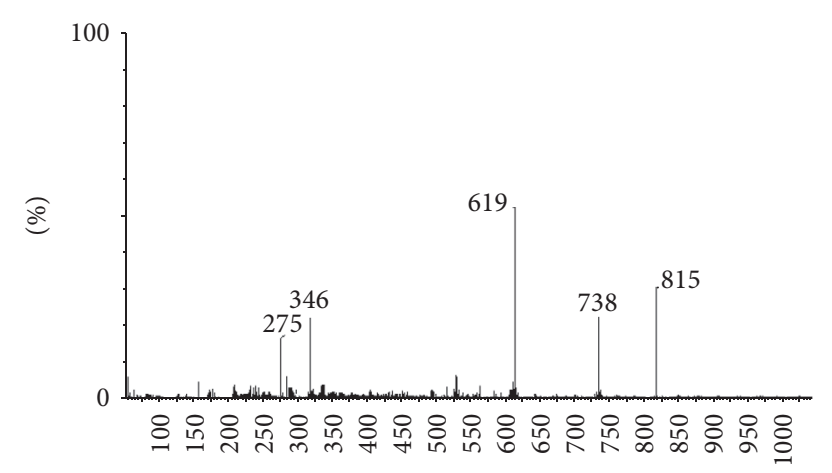

$(m / z)$

Figure 7: Mass spectrum of heterobimetallic complex [Cu $\left.\left(\mathrm{C}_{6} \mathrm{H}_{6} \mathrm{~N}_{2}\right)_{2} \mathrm{Sn}_{2}\left(\mathrm{C}_{6} \mathrm{H}_{5}\right)_{4} \mathrm{Cl}_{2}\right]$.

a distorted octahedral geometry for these complexes with $d_{z^{2}}$ as the ground state of the system [13]. On this basis, it is concluded that chloride ions coordinate with $\mathrm{Cu}$ (II) on complexation with $\mathrm{R}_{2} \mathrm{M}^{\prime} \mathrm{Cl}_{2}$ achieving an octahedral environment for copper.

3.3. Electronic Spectra. The electronic spectrum of monometallic complex exhibits a strong $d$ - $d$ band at $594 \mathrm{~nm}$ which is characteristic of square planar complexes. A band is also obtained at $247 \mathrm{~nm}$ which is ascribed to $\mathrm{L} \rightarrow$ M charge transfer. The electronic spectrum of complexes exhibits a strong band at $277 \mathrm{~nm}$ and shoulders assignable to intraligand transition and ligand to metal charge transfer [14]. In bimetallic octahedral complexes of copper, distortion may lead to dislodgment of $d$ - $d$ bands to lower energies and hence two bands are observed at $920 \mathrm{~nm}$ and $880 \mathrm{~nm}$.

3.4. Molar Conductance. The molar conductance values of heterobimetallic complexes in DMF solution fall in the range of $18-33 \mathrm{ohm}^{-1} \mathrm{~mol}^{-1} \mathrm{~cm}^{2}$ suggesting that they are nonelectrolytes while higher conductance value of mononuclear complex of about $220 \mathrm{ohm}^{-1} \mathrm{~mol}^{-1} \mathrm{~cm}^{2}$ indicates the electrolytic character [15].

3.5. Mass Spectroscopy. The FAB mass spectra of the heterobimetallic complex $\left[\mathrm{Cu}\left(\mathrm{C}_{6} \mathrm{H}_{6} \mathrm{~N}_{2}\right)_{2} \mathrm{Sn}_{2}\left(\mathrm{C}_{6} \mathrm{H}_{5}\right)_{4} \mathrm{Cl}_{2}\right]$ exhibited molecular ion peaks at $m / z$ 815, 738, 619, and 346 assigned to $\left[\mathrm{Cu}\left(\mathrm{C}_{6} \mathrm{H}_{6} \mathrm{~N}_{2}\right)_{2} \mathrm{Sn}_{2}\left(\mathrm{C}_{6} \mathrm{H}_{5}\right)_{3} \mathrm{Cl}_{2}\right]^{+},\left[\mathrm{Cu}\left(\mathrm{C}_{6} \mathrm{H}_{6} \mathrm{~N}_{2}\right)_{2}\right.$ $\left.\mathrm{Sn}_{2}\left(\mathrm{C}_{6} \mathrm{H}_{5}\right)_{2} \mathrm{Cl}_{2}\right]^{+},\left[\mathrm{Cu}\left(\mathrm{C}_{6} \mathrm{H}_{6} \mathrm{~N}_{2}\right)_{2} \mathrm{Sn}\left(\mathrm{C}_{6} \mathrm{H}_{5}\right)_{2} \mathrm{Cl}_{2}\right]^{+}$, and $[\mathrm{Cu}$ $\left.\left(\mathrm{C}_{6} \mathrm{H}_{6} \mathrm{~N}_{2}\right)_{2} \mathrm{Cl}_{2}\right]^{+}$, respectively. The two coordinated chlorides are removed with a mass loss of $m / z=71$ with peak obtained at $m / z=275$ (Figure 7).

3.6. X-Ray Powder Diffraction Studies. The possible geometry of the finely powdered sample of the compound $\left[\mathrm{Cu}\left(\mathrm{C}_{6} \mathrm{H}_{8} \mathrm{~N}_{2}\right)_{2}\right] \mathrm{Cl}_{2}$ has been inferred on the basis of $\mathrm{X}$ ray powder diffraction studies (Figure 8). The observed interplanar spacing values (" $d$ " in $\AA$ ) have been measured from the diffractogram of this compound and the Miller indices $h, k$, and $l$ have been assigned to each $d$ value as reported in Table 8 . The results show that compound belongs 
TABLE 8: X-ray powder diffraction data for the compound $\left[\mathrm{Cu}\left(\mathrm{C}_{6} \mathrm{H}_{8} \mathrm{~N}_{2}\right)_{2}\right] \mathrm{Cl}_{2}$.

\begin{tabular}{lccccc}
\hline Peak number & $2 \theta$ (deg.) (obs.) & $h$ & $k$ & $l$ & $d$-spacing (obs.) \\
\hline$(1)$ & 11.30 & 1 & 2 & 0 & 9.765 \\
$(2)$ & 11.50 & 2 & 1 & 0 & 9.669 \\
$(3)$ & 15.80 & 0 & 5 & 0 & 7.048 \\
$(4)$ & 19.80 & 2 & 5 & 0 & 5.634 \\
$(5)$ & 21.92 & 4 & 0 & 0 & 5.095 \\
$(6)$ & 21.98 & 4 & 0 & 1 & 5.125 \\
$(7)$ & 25.80 & 3 & 3 & 1 & 4.339 \\
$(8)$ & 26.28 & 1 & 6 & 1 & 4.261 \\
$(9)$ & 26.27 & 1 & 5 & 1 & 4.41 \\
$(10)$ & 27.20 & 3 & 4 & 1 & 4.120 \\
$(11)$ & 30.40 & 2 & 7 & 0 & 3.695 \\
$(12)$ & 30.48 & 7 & 2 & 0 & 3.799 \\
$(13)$ & 33.40 & 6 & 0 & 1 & 3.371 \\
$(14)$ & 34.42 & 0 & 6 & 0 & 3.426 \\
$(15)$ & 38.10 & 3 & 9 & 3 & 2.968 \\
$(16)$ & 43.30 & 5 & 10 & 3 & 1.970 \\
$(17)$ & 58.90 & 4 & 3 & & 1.706 \\
$(18)$ & 58.10 & 2 & 0 & & \\
\hline
\end{tabular}

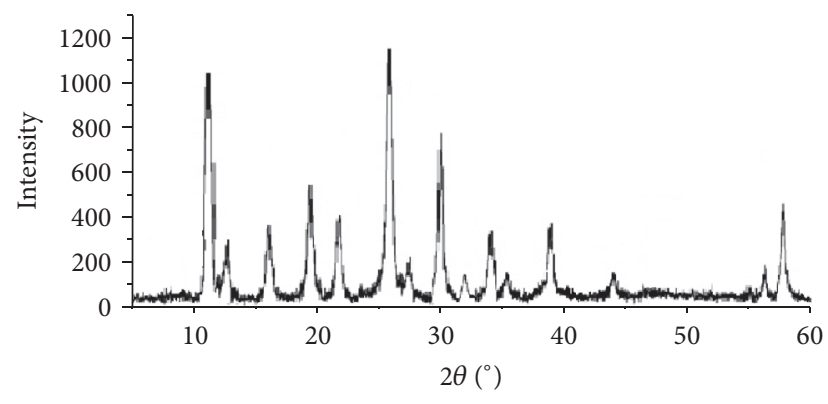

FIGURE 8: X-ray diffraction pattern of compound $\left[\mathrm{Cu}\left(\mathrm{C}_{6} \mathrm{H}_{8} \mathrm{~N}_{2}\right)_{2}\right]$ $\mathrm{Cl}_{2}$.

to "orthorhombic" crystal system having unit call parameters as

$$
\begin{aligned}
& a=21.430, \\
& b=33.640, \\
& c=5.430 ; \\
& \alpha=\beta=\gamma=90^{\circ} .
\end{aligned}
$$

Refined values of $a=21.430, b=33.640, c=5.430$; $\alpha=\beta=\gamma=90^{\circ}$ (orthorhombic system).

On the basis of above spectral studies, the structure can be suggested for mononuclear and heterobimetallic complex, respectively. See Figure 9.

\subsection{Biological Evaluation}

(i) Antimicrobial Activities. The results described in Tables 1 and 2 reveal that all the compounds are active against these organisms even at low concentrations, and the inhibition of the growth of microorganism was found to be dependent on the concentration of the compounds [6]. The results of the biological screening indicated that the heterobimetallic complexes exhibit effective antifungal activity against fungal strain F. oxysporum; however, antibacterial activity was found to be brilliant in case of Gram-negative bacteria as compared to Gram-positive bacteria. The difference arises due to variation in the thickness of peptidoglycan layer which is more in Gram-positive as compared to Gram-negative bacteria leading to difficult penetration across the cell wall.

\section{(ii) Antifertility Activity}

Effect on Organ Weights. The current study revealed that administration of monometallic complex and their various heterobimetallic complexes at the dose level of $30 \mathrm{mg} / \mathrm{Kg}$ body weight for 60 days ensued in a substantial reduction in weight of testes and other sex organs (Table 4). The reduction in testicular weight may be due to reduced tubule size, spermatogenic arrest, and inhibition of steroid biosynthesis of Leydig cells [16]. Diminutions in the weight of accessory reproductive organs directly support the curtailed availability of androgen [17].

Effect on Sperm Density. Sperm density of the testis and cauda epididymides was decreased significantly $(P \leq 0.001)$ in rats treated with the complexes at all the dose levels (Table 3 ). The low sperm density in cauda epididymis is caused by the alternation in androgen level.

Effect on Fertility. A 35-90\% negative fertility was observed for heterobimetallic complexes (Table 3). The negative fertility test is credited to lack of forward progression and reduction in density of spermatozoa and altered biochemical milieu of cauda epididymis [18]. 


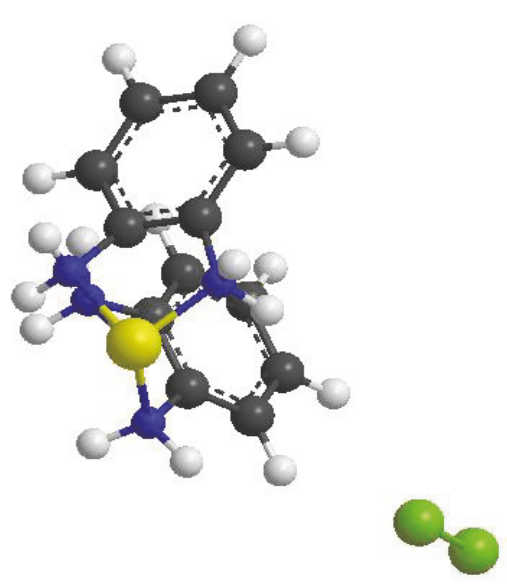

Mononuclear complex

$\left[\mathrm{Cu}\left(\mathrm{C}_{6} \mathrm{H}_{8} \mathrm{~N}_{2}\right)_{2}\right] \mathrm{Cl}_{2}$

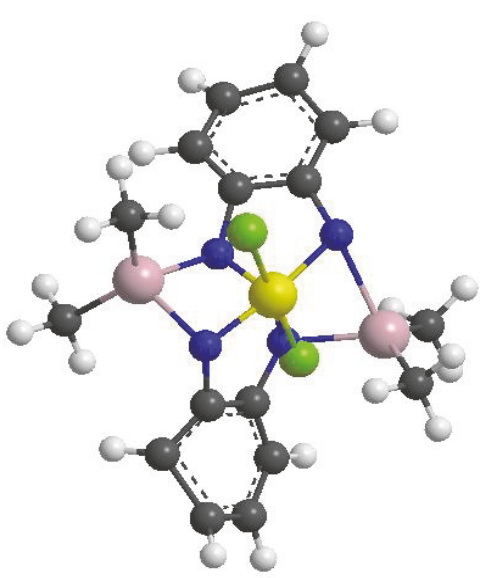

Heteronuclear complex

$\left[\mathrm{Cu}\left(\mathrm{C}_{6} \mathrm{H}_{6} \mathrm{~N}_{2}\right)_{2} \mathrm{Sn}_{2}(\mathrm{Me})_{4} \mathrm{Cl}_{2}\right]$

Figure 9

Effect on Cholesterol Levels. It has been observed that the concentration of cholesterol increases in testes (Table 5). This increased concentration of testicular cholesterol may be the result of nonutilization leading to the reduction of production of the hormone which is involved in the control of fertility of animals including rats [19]. It is therefore concluded that the heterobimetallic complexes of copper are more effective than the monometallic complexes in inhibiting the fertility due to the synergistic action.

\section{Conclusion}

In this paper, we describe the synthesis of monometallic and heterobimetallic complexes of copper which are further characterized by IR, ESR, and electronic and mass spectral studies. These studies evidently propose square planar and octahedral geometry for mono- and heterobimetallic complexes, respectively. These complexes were then evaluated for their antifungal, antibacterial, and antifertility activity. The antimicrobial results indicated that the heterobimetallic complexes exhibited promising activity against microbes as compared to mononuclear complexes. However, the results obtained revealed that these complexes exhibited utmost activity against fungal strain F. oxysporum and bacterial strain E. coli. The results drawn from antifertility activity suggested the efficiency of the synthesized heterobimetallic complexes in reducing fertility more effectively than the mononuclear complexes of copper from which they have been derived and thus play an imperative role in improving bioactivity.

\section{Conflicts of Interest}

The authors declare that they have no conflicts of interest.

\section{Acknowledgments}

The authors (Ashu Chaudhary and Anshul Singh) wish to express gratitude to the Council of Scientific and Industrial
Research (CSIR), New Delhi, India, for financial assistance in the form of JRF vide Letter no. 09/105(0221)/2015-EMR-I.

\section{References}

[1] C. M. Thomas, "Metal-metal multiple bonds in early/late heterobimetallic complexes: Applications toward small molecule activation and catalysis," Comments on Inorganic Chemistry, vol. 32, no. 1, pp. 14-38, 2011.

[2] M. Rakkiyasamy, K. Kalimuthu, and S. Rangasamy, "Heterobimetallic complexes of transition metals-synthesis and characterization," Journal of Chemical Biological and Physical Sciences Section A, vol. 3, no. 1, pp. 16-19, 2012.

[3] B. G. Cooper, J. W. Napoline, and C. M. Thomas, "Catalytic applications of early/late heterobimetallic complexes," Catalysis Reviews - Science and Engineering, vol. 54, no. 1, pp. 1-40, 2012.

[4] R. K. Al-Shemary, A. M. A. Al-Khazraji, and A. F. S. S. M. Lateef, "Synthesis, characterization and antimicrobial activity studies of mixed-1,10-phenanthroline-Mn(II), $\mathrm{Co}(\mathrm{II}), \mathrm{Cu}$ (II), $\mathrm{Ni}(\mathrm{II})$ and $\mathrm{Hg}(\mathrm{II})$ complexes with schiff base[2,2'-(1Z,1'Z)(biphenyl-4,4'-diylbis(azan-1-yl-1-ylidene))bis(methan-1-yl1-ylidene)diphenol]," International Journal of Science and Research (IJSR), vol. 5, no. 5, pp. 1787-1793, 2016.

[5] A. A. Osowole, O. B. A. Agbaje, and B. O. Ojo, "Synthesis, characterization and antibacterial properties of some heteroleptic metal(II) complexes of paracetamol and vanillin," Asian Journal of Pharmaceutical and Clinical Research, vol. 7, no. 3, pp. 145149, 2014.

[6] K. Sharma, R. V. Singh, and N. Fahmi, "Palladium(II) and platinum(II) derivatives of benzothiazoline ligands: synthesis, characterization, antimicrobial and antispermatogenic activity," Spectrochimica Acta-Part A: Molecular and Biomolecular Spectroscopy, vol. 78, no. 1, pp. 80-87, 2011.

[7] N. Fahmi, A. Kumari, and R. V. Singh, "Synthesis, characterization, antimicrobial and pesticidal activity of organoarsenic(III) and organoantimony(III) complexes with NnS donor ligands," International Journal of Pharmaceutical Sciences and Research, vol. 5, no. 12, pp. 5260-5266, 2014. 
[8] S. Yadav, A. Moheman, and K. S. Siddiqi, "Synthesis and characterization of heterobimetallic complexes of the type [Cu(pn)2][MCl4] where $\mathrm{M}=\mathrm{Co}(\mathrm{II}), \mathrm{Ni}(\mathrm{II}), \mathrm{Cu}(\mathrm{II}), \mathrm{Zn}(\mathrm{II})$, $\mathrm{Cd}(\mathrm{II})$, and $\mathrm{Hg}(\mathrm{II})$," Arabian Journal of Chemistry, vol. 9, no. 2, pp. S1747-S1754, 2016.

[9] M. Chauhan, K. Banerjee, and F. Arjmand, "DNA binding studies of novel copper(II) complexes containing L-tryptophan as chiral auxiliary: In vitro antitumor activity of $\mathrm{Cu}-\mathrm{Sn} 2$ complex in human neuroblastoma cells," Inorganic Chemistry, vol. 46, no. 8, pp. 3072-3082, 2007.

[10] S. Tabassum, M. Zaki, F. Arjmand, and I. Ahmad, "Synthesis of heterobimetallic complexes: In vitro DNA binding, cleavage and antimicrobial studies," Journal of Photochemistry and Photobiology B: Biology, vol. 114, pp. 108-118, 2012.

[11] U. Kumar and S. Chandra, "Synthesis, spectral and antifungal studies of some coordination compounds of cobalt(II) and copper(II) of a novel 18-membered octaaza [N8] tetradentate macrocyclic ligand," Journal of Saudi Chemical Society, vol. 15, no. 2, pp. 187-193, 2011.

[12] F. Arjmand, B. Mohani, and S. Parveen, "New Dihydro OO'Bis (Salicylidene) 2,2' aminobenzothiazolyl borate complexes: kinetic and voltammetric studies of dimethyltin copper complex with guanine, adenine, and calf thymus DNA," Bioinorganic Chemistry and Applications, vol. 2006, Article ID 32896, 10 pages, 2006.

[13] K. S. Siddiqi, H. Afaq, S. A. A. Nami, and A. Umar, "Heterobimetallic complexes containing $\mathrm{Cu}$ and $\mathrm{Si}$," Synthesis and Reactivity in Inorganic and Metal-Organic Chemistry, vol. 33, no. 8, pp. 1459-1468, 2003.

[14] K. Nagaraj, S. Sakthinathan, and S. Arunachalam, "Synthesis, CMC determination, antimicrobial activity and nucleic acid binding of a surfactant Copper(II) complex containing phenanthroline and alanine schiff-base," Journal of Fluorescence, vol. 24, no. 2, pp. 589-598, 2014.

[15] A. Chaudhary, N. Bansal, N. Fahmi, and R. V. Singh, "Toxicological aspects of newly designed macrocyclic complexes of iron(II)," Indian Journal of Chemistry, vol. 43A, pp. 320-322, 2004.

[16] S. C. Joshi, P. Tibrewal, A. Sharma, and P. Sharma, "Evaluation of toxic effect of 2,4-d (2,4-dichlorophenoxyacetic acid) on fertility and biochemical parameters of male reproductive system of albino rats," International Journal of Pharmacy and Pharmaceutical Sciences, vol. 4, no. 3, pp. 338-342, 2012.

[17] S. C. Joshi, R. Mathur, A. Gajraj, and T. Sharma, "Influence of methyl parathion on reproductive parameters in male rats," Environmental Toxicology and Pharmacology, vol. 14, no. 3, pp. 91-98, 2003.

[18] S. C. Joshi, B. Bansal, and N. D. Jasuja, "Evaluation of reproductive and developmental toxicity of cypermethrin in male albino rats," Toxicological and Environmental Chemistry, vol. 93, no. 3, pp. 593-602, 2011.

[19] P. Kapoor, S. C. Joshi, R. V. Singh, and N. Fahmi, "Antispermatogenic activity of later transition metal complexes of Benzothiazolines derived from substituted coumarins in male rats," World Journal of Pharmaceutical Research, vol. 5, no. 2, pp. 1056-1068, 2016. 

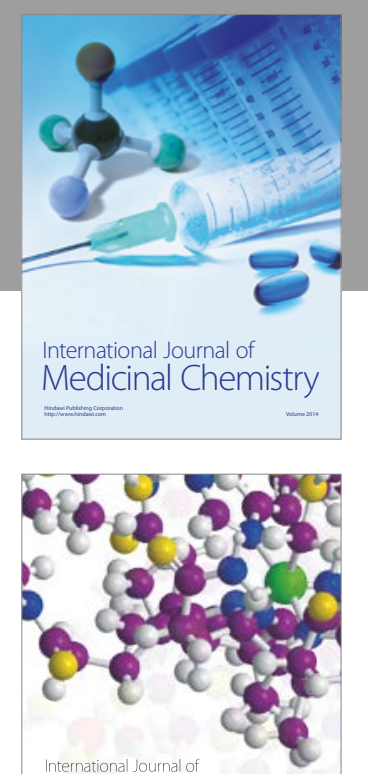

Carbohydrate Chemistry

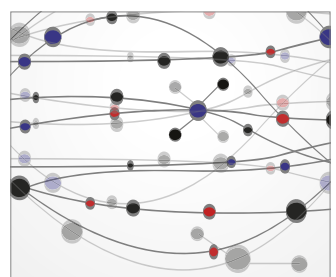

The Scientific World Journal
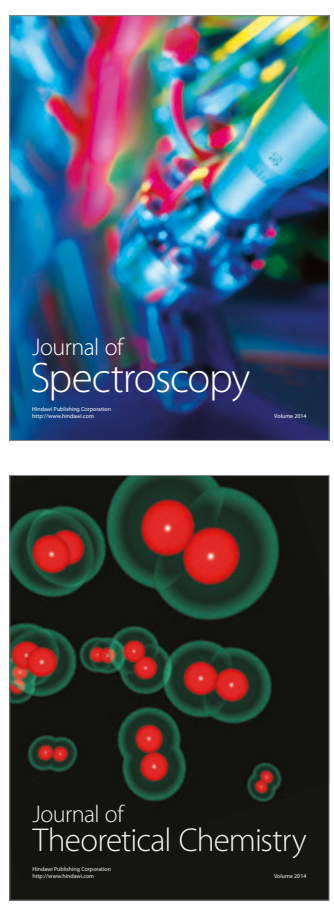
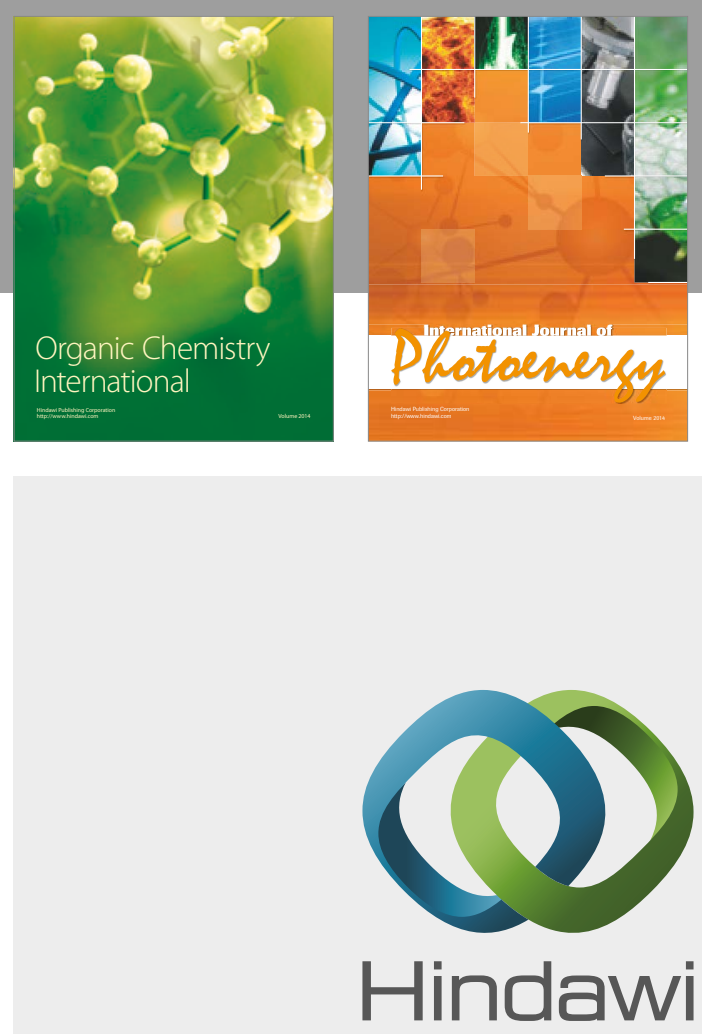

Submit your manuscripts at

https://www.hindawi.com

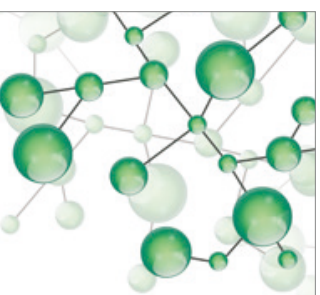

International Journal of

Inorganic Chemistry

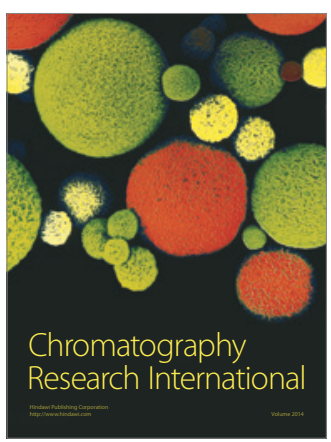

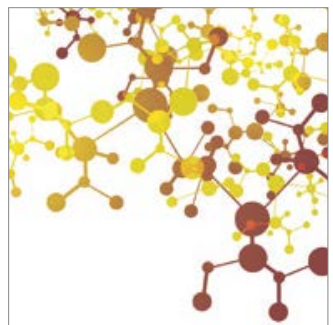

Applied Chemistry
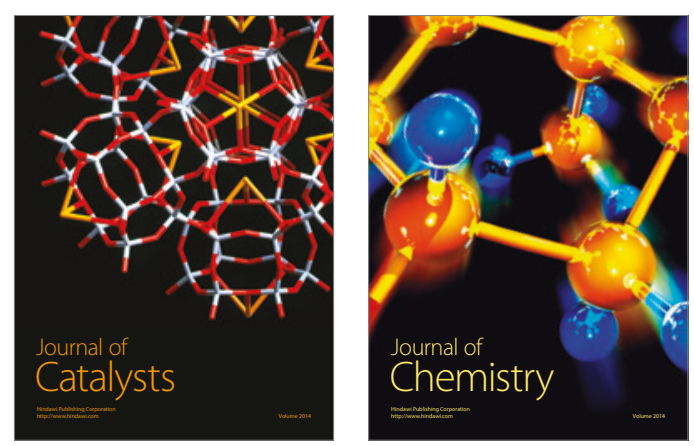
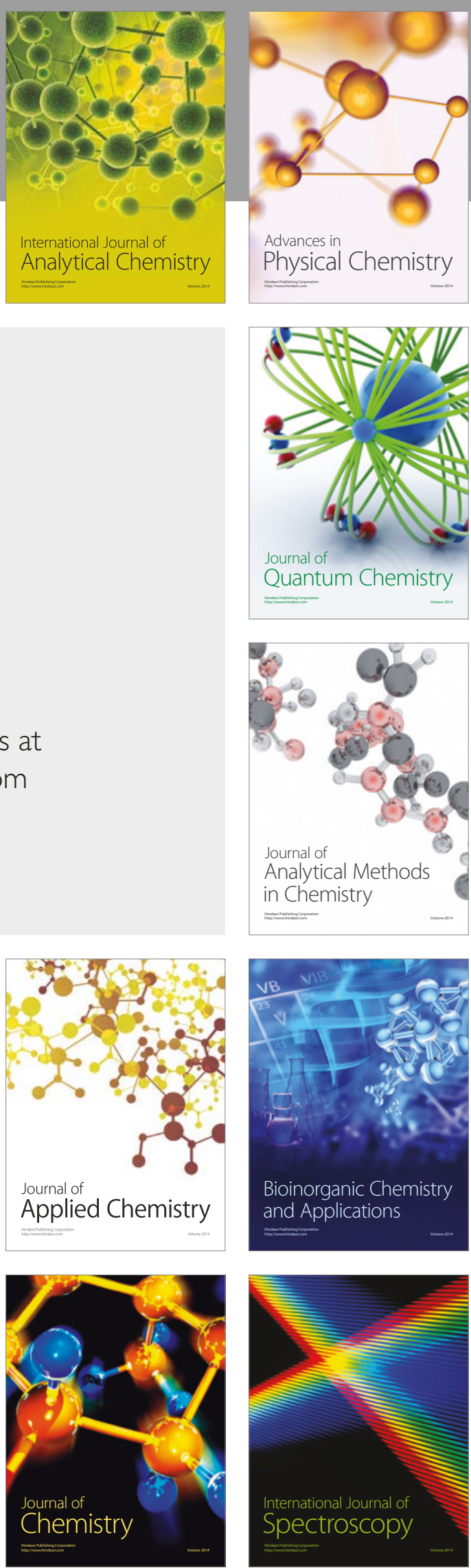